\title{
PROSOCIAL CROWDLENDING IN KENYA
}

\author{
Alberto lbarra \\ Natàlia Cugueró-Escofet \\ Miguel Ángel Canela
}




\title{
PROSOCIAL CROWDLENDING IN KENYA
}

\author{
Alberto Ibarra' \\ Natàlia Cugueró-Escofet ${ }^{2}$ \\ Miguel Ángel Canela ${ }^{3}$
}

\section{Abstract}

The crowdfunding industry has emerged in the past few years as one of the most promising alternative financing options. Lending and donating operations accounted for $81 \%$ of the crowdfunding industry's \$34.4 billion total funding volume in 2015.

Kiva Zip, a prosocial program, created an online platform that provides 0\% interest peer-to-peer loans and has features in common with lending and donating crowdfunding platforms. This program is a spin-off of Kiva.org. Although both platforms have a similar objective and modus operandi, they differ primarily because Kiva.org has a figure called a field partner, who is the intermediary between borrowers and lenders, while Kiva Zip has no field partners but does have so-called trustees, who provide support to borrowers but do not act as intermediaries for resources or charge for their services.

The authors thoroughly analyzed Kiva Zip's operations in Kenya for the years from 2011 to 2015. Kiva Zip has stopped posting new campaigns in Kenya but has continued to collect payment for previously delivered loans. We studied in detail the impact that lenders, borrowers and trustees had on the platform's performance. In addition, we analyzed the different stages of a campaign on Kiva Zip: when a campaign is posted, when it is funded and when the loan is paid back.

This analysis may provide insight into the levers that drove the performance of Kiva Zip in Kenya, which in turn could have enabled the organization to identify areas for improvement in order to continue operating in the country.

In addition, we have identified relevant theoretical frameworks for analyzing prosocial crowdlending in greater depth.

JEL Classification: M1

Keywords: Crowdfunding; Crowdlending; peer-to-peer; Kenya; Africa; Funding; Entrepreneurship.

\footnotetext{
${ }^{1}$ Assistant Professor of decision analysis, IPADE Business School. Al.ibarra@ipade.mx

${ }^{2}$ Assistant Professor of management control, Universitat Oberta de Catalunya. NCuguero@iese.edu

${ }^{3}$ Associate Professor, Managerial Decision Sciences, IESE. MCanela@iese.edu
} 


\section{Contents}

1 Introduction 2

1.1 The Crowdfunding Industry 2

1.2 Kiva.org 3

1.3 Kiva Zip Program 4

2 Theoretical Context 5

3 Kiva Zip 8

3.1 Kiva Zip in Kenya 10

4 Methodology 11

4.1 Capturing the Data 11

$\begin{array}{lll}4.2 & \text { Processing the Data } & 13\end{array}$

4.3 Methods of Analysis 13

5 Stakeholder Analysis $\quad 14$

$\begin{array}{lll}5.1 & \text { Lenders } & 14\end{array}$

$\begin{array}{lll}5.2 & \text { Trustees } & 16\end{array}$

$\begin{array}{llr}5.3 & \text { Borrowers } & 18\end{array}$

6 Campaign Stage Analysis 20

6.1 Campaign Creation 20

6.2 Campaign Funding 25

6.3 Repayment of Loans 29

$7 \quad$ Further Research 33

$8 \quad$ Concluding Remarks 34

$9 \quad$ References $\quad 35$ 


\section{PROSOCIAL CROWDLENDING IN KENYA}

\section{Introduction}

\subsection{The Crowdfunding Industry}

The crowdfunding industry has emerged in the past few years as one of the most promising alternative financing options. The compound annual growth rate was 133.56\% (see Tables 1 and 2) for the period between 2012 and $2015 .^{1}$

The industry is primarily divided into the following categories (Kshetri, 2015):

1. Donation-based crowdfunding: models where the main goal is to give a contribution to others with no expectation of any reward or compensation.

2. Reward-based crowdfunding: campaigns where the supporter receives a product, service or recognition for aiding the project.

3. Lending-based crowdfunding: a debt-based model, where the borrower receives money and has the obligation of paying back to the lender the capital plus interest at an agreed rate. This can be peer-to-peer lending (P2P) or peer-to-business (P2B).

4. Equity-based crowdfunding: a model where business ventures are funded through the provision of equity.

Crowdlending represented 73\% of the crowdfunding industry in 2015 and grew by 126\% from 2014 to $2015 .^{2}$ Following the relevance of the industry and the crowdlending segment, we decided to carry out a thorough analysis of the Kiva Zip platform developed by Kiva.org. The latter is an organization that developed a prosocial crowdlending platform that enabled "interest-free" peerto-peer lending. In the following two sections (2.2 and 2.3), we will describe Kiva.org and Kiva Zip in full.

\footnotetext{
${ }^{1} \mathrm{http}: / /$ www.crowdsourcing.org/editorial/global-crowdfunding-market-to-reach-344b-in-2015-predicts-massolutions-2015cfindustry-report/45376, last accessed November 2016.

${ }^{2} \mathrm{http}: / /$ www.crowdsourcing.org/editorial/global-crowdfunding-market-to-reach-344b-in-2015-predicts-massolutions-2015cfindustry-report/45376, last accessed November 2016. 


\section{Table 1}

Total crowdfunding industry funding by year (billions of U.S. dollars)

\begin{tabular}{cc}
\hline Year & Total funding \\
\hline 2012 & 2.7 \\
2013 & 6.1 \\
2014 & 16.2 \\
2015 & 34.4 \\
\hline
\end{tabular}

Source: Prepared by the authors based on Massolution/Crowdsourcing.org 2015CF Crowdfunding Industry Report, http://reports.crowdsourcing.org/index.php?, last accessed February 2017.

\section{Table 2}

Total crowdfunding industry funding by platform model (billions of U.S. dollars)

\begin{tabular}{lc}
\hline Platform model & $\begin{array}{c}\text { Total funding } \\
\text { in 2015 }\end{array}$ \\
\hline Donation & 2.9 \\
Reward & 2.7 \\
Lending & 25.1 \\
Equity & 2.6 \\
Royalty & 0.4 \\
Hybrid & 0.8 \\
Total & 34.4 \\
\hline
\end{tabular}

Source: Prepared by the authors based on Massolution/Crowdsourcing.org 2015CF Crowdfunding Industry Report, http://reports.crowdsourcing.org/index.php?, last accessed February 2017.

\subsection{Kiva.org}

Kiva.org is an international organization founded in 2005 that created an Internet platform for crowdlending campaigns. The platform has three main stakeholders: lenders (those who provide loans), borrowers (those who receive the funds and consequently acquire the debt) and partners (those who help borrowers to develop campaigns and follow up on their execution and the repayment of loans). Through September 2016, the platform had enabled close to $\$ 900$ million in "interest-free" loans. ${ }^{3}$ However, borrowers may end up paying a fee to partners for their services. In those cases, borrowers will not receive 100\% of the resources but will still accrue a debt for the full size of the loan (what they receive plus the partner's fees). In cases where the borrower has to pay the partner a fee, there is an implicit interest payment since the borrower has to pay back the total amount of the loan. On the other hand, when partners do not charge borrowers anything for their services, the loan is effectively interest free. On the upside, a partner's mediation allows Kiva.org to have an on-site stakeholder who can apply quality-control mechanisms to minimize the likelihood of fraud and enhance compliance on the part of borrowers. On the downside, partners may become a bottleneck when the platform wants to scale operations and they may also charge commission for their services, thus decreasing the amount received by borrowers. This state of affairs led Kiva.org to develop Kiva Zip as an alternative online crowdlending program.

\footnotetext{
3 “Kiva by the Numbers," Kiva website, https://www.kiva.org/about, accessed September 2016.
} 


\subsection{Kiva Zip Program}

In September 2011, Kiva Zip was created by Kiva.org as a beta program. This new development represented a shift from the previous lending model: there would be no more field partners. Instead, all resources would be sent directly from lenders to borrowers. However, a new figure called a trustee was created: this person would be responsible for helping borrowers and providing follow-up on how the borrower's campaign was developing, but without being responsible for the repayment of debt in the case of late payments or defaults. Kiva Zip was launched in Kenya and the United States, but it is currently operating only in the United States, under the name Kiva U.S. ${ }^{4}$ This article focuses on the campaigns listed by Kiva Zip in Kenya from November 2011 to September 2015.

During these four years, Kiva Zip Kenya listed 9,640 peer-to-peer lending campaigns. Of those, 9,621 were fully funded, for a total amount of $\$ 1,837,351$. After discontinuing new campaigns in Kenya in September 2015, Kiva Zip continued only with the collection of previously granted loans. Up to December 26, 2015, 76\% of all funded campaigns had been paid back, accounting for $70 \%$ of all the resources granted. According to Kiva Zip, it discontinued the provision of new loans in Kenya due to the high number of late payments (18\% of loans were late in being repaid: $44 \%$ of these by less than six months and $56 \%$ by six months or more, so the latter could be regarded as defaulted) as well as problems with managing trustees.

Lenders may have approached this platform in order to help entrepreneurs who needed it the most or those borrowers with whom they identified the most. Lenders were willing to provide loans at $0 \%$ interest and assume 100\% of the risk of late payments. Kiva Zip does not have robust enforcement measures to collect late loan payments, so lenders are vulnerable to noncompliance by borrowers. Considering that $99.8 \%$ of all campaigns were funded under the previous circumstances, it seems that lenders had intrinsic motivations for helping borrowers through Kiva Zip.

Consequently, Kiva Zip's decision to discontinue loans in Kenya may go against the interests of some of its borrowers, lenders and trustees. First, it goes against borrowers who need access to low-cost debt. Such borrowers reside in a country where the GDP per capita is less than 5\% that of the United States and where the poverty rate is close to $40 \%$ of the population. Second, the decision goes against lenders who are willing to risk their resources in order to fund projects that have a social impact. And last, it goes against the trustees, who do not receive any direct reward for their work but who generously provide advice and follow-up to borrowers.

In addition to compromising the relationship with its main stakeholders, Kiva Zip may have gone against its own mission, which is "to connect people through lending to alleviate poverty." This stated mission reinforces the magnanimous objective of making the Kenyan endeavor a successful one instead of deciding to have Kiva Zip continue solely in the United States, where there is less poverty. Kiva Zip has proven to be a program that can develop vulnerable communities, so a focus on how to improve and increase operations in Kenya may be better aligned with Kiva Zip's own mission and the will of its stakeholders, as opposed to moving toward less impoverished areas.

\footnotetext{
${ }^{4}$ Suzanna Rush, "Using Business Credit Scores to Graduate Borrowers," Kiva blog, June 8, 2016, https://borrow.kiva.org/blogs/225.
} 
Consequently, we have conducted a series of statistical analyses in order to understand better the variables that are relevant to the likelihood of campaigns being funded successfully and the loans being paid back subsequently. These analyses may provide insight into how Kiva Zip Kenya could have been a more successful venture.

Finally we have explored the theoretical context relevant to the analysis of prosocial crowdlending. Although this exploration does not aim to be exhaustive, it is done with the intention of investigating the most relevant aspects, as perceived by the authors of this paper, that should be pursued in further research.

\section{Theoretical Context}

The crowdfunding industry is developing into a serious financing alternative for profit and nonprofit ventures. While the industry continues expanding thanks to the development of crowdsourcing technology, information technology, data analysis software, the platform economy and social media, there is a need for managerial research to analyze the industry as a whole and the relevant phenomena surrounding it.

The authors have identified the following perspectives as ideal subjects for research based on the available Kiva Zip data. These theoretical approaches do not exhaust the possible research agenda but are of interest to the authors because of the topics' relevance to the academic and managerial worlds.

1. Management Control Systems

a. Control mechanisms: Kiva Zip utilizes, whether deliberately or not, a series of mechanisms that control the activities carried out via its website in order to achieve its goals, namely to alleviate poverty by funding entrepreneurial ventures. A starting point for approaching this topic could be to analyze how market, bureaucratic and clan mechanisms (Ouchi, 1979) impact the performance of Kiva Zip in Kenya.

b. Justice and goal congruence: all crowdfunding websites are developed in order to accomplish certain goals. In addition, certain procedures are established so that crowdfunding campaigns are just and adhere to organizational values. These procedures are considered part of the formal justice system but they also complement certain informal practices that enable (or do not enable) the justice system to be aligned with the firm's goals (Cugueró-Escofet et al., 2016). We wish to analyze how Kiva Zip's controls are aligned with its overall mission.

c. Object of control: every platform develops certain controls that enable its stakeholders to interact. These controls complement each other but can be designed individually to deter or encourage specific behavior on the part of both campaign creators and supporters. However, these controls may be targeted at different objects: actions, personnel or results (Merchant, 1982). We wish to identify the extent to which these controls deter late payment in Kiva Zip's campaigns in Kenya. 


\section{Cross-Cultural Implications}

a. Cultural dimensions: technology has enabled the crowdfunding industry to flourish and to enhance the national and international coverage of platforms. However, there should be certain cultural dimensions that affect the behavior of the industry's stakeholders. The analysis of how "individualism versus collectivism, large or small power distance, strong or weak uncertainty avoidance, and masculinity versus femininity" (Hofstede, 1983) affect the performance of Kiva Zip's campaigns in Kenya may provide insight for a better understanding of the industry. In particular, performance may be seen to vary in different regions of Kenya.

b. Methodological approach: the crowdfunding industry is far from mature. It is still developing and new platforms are emerging to satiate growing demand. In addition, these new platforms vary greatly since they may be for profit or notfor-profit; they may be aimed at securing rewards, donations, equity or lending; they may be located in the United States, the United Kingdom or another country; and they may show similarities with and differences from the traditional banking and venture capital world. This growth requires in-depth analysis, where researchers would seek to develop universal statements regarding how the industry operates. However, cross-cultural implications must be taken in account for further research. Consequently, this calls for diligent work in terms of the approach to the analysis, which could be "parochial, ethnocentric, polycentric, comparative, geocentric or synergistic" (Adler, 1983). For this particular paper, we wish to understand the approach that must be taken to see how Kiva Zip's operations in Kenya are similar to or different from other platforms in the same or different regions.

3. Asymmetric Information

a. Quality uncertainty: most, if not all, commercial transactions take place with a certain degree of asymmetric information in which one party has private information. This is the case in crowdfunding campaigns. The campaign creator has more detail about the project to be developed than the campaign supporter. In addition, the campaign has its own market risk, of which neither the creator nor the supporter may be fully aware. There is a risk of dishonesty in addition to the project's embedded risk, so platforms must design procedures to minimize the problem while counteracting institutions may complement the effort made by crowdfunding firms (Akerlof, 1970). Kiva Zip's operations in Kenya provide an opportunity to understand the impact that specific campaign characteristics have on its success.

b. Adverse selection and moral hazard: a crowdfunding platform is more successful, generally speaking, when it has more funded campaigns and when those campaigns fulfill the established promise. However, developing more campaigns has a downside in terms of control. It is difficult for a platform to avoid "adverse selection" (Pauly, 1974) since it may attract inexperienced entrepreneurs who do not have access to traditional financing alternatives. This may lead to what is considered in economics as adverse selection. Once a campaign is funded, platforms may also confront a "moral hazard" (Pauly, 
1974) since the campaign creators may deviate from desired behavior once they have been funded. This is possible since platforms and supporters have little possibility of correcting and few incentives to correct undesired behavior by campaign creators (Ibarra Garza et al., 2016). We wish to analyze the sustainability of Kiva Zip and the rest of the industry in light of confronting adverse selection and moral hazards.

4. Financial Economics

a. Funding patterns: it is important to understand what variables are related to the successful funding of crowdfunding campaigns, particularly in Kiva Zip's campaigns in Kenya. In addition, we must analyze in depth the "contribution pattern" (Burtch et al., 2013) since this can help us understand the funding behavior of a crowdfunding campaign. (For example, does early-stage funding allow overall funding success to be predicted?) In addition, it is useful to understand the "funding determinants" (Jeng et al., 2000) of Kiva Zip's campaigns since this may help us predict whether funding will be successful before a campaign is posted. (For example, does a borrower's experience have a positive effect on the likelihood of a campaign being funded?)

b. Default prediction: a critical element for Kiva Zip's sustainability is the repayment of the loans. Consequently, the analysis of the variables that affect the probability of a loan default may allow the authors to understand peer-topeer lending better. This research may identify an algorithm that predicts a default at an early stage (before, during or after funding). This knowledge system could be compared with "individual and group judgements" (Messier et al., 1988) in order to deduce the best knowledge systems for predicting defaulting campaigns.

5. The Wisdom of Crowds

a. Evaluation of "the wisdom of crowds" (Surowiecki, 2005): by definition, crowdfunding campaigns are funded by crowds, which, according to Surowiecki, are better decision makers than experts when they reflect a diverse base of people, when their decisions are independent of each other and when the individuals in the group have private or decentralized information. In this case, it is beneficial to understand whether or not the crowds are good decision makers according to this standard. Two major concerns are that Kiva Zip's users may not be very different from each other and that individual lenders' decisions may depend on the rest of the crowd's decision making. Both conditions, if present, could affect the quality of decision making among the crowd supporting a campaign.

These five topics are relevant for further research, which could be based on the data set obtained from Kiva Zip's operations in Kenya. Nevertheless, some additional methods (such as interviews, surveys and qualitative analysis) may provide complementary information for our research purposes. 


\section{Kiva Zip}

Kiva Zip is a program developed by Kiva.org, which is a crowdlending (peer-to-peer) firm. There are two main differences between Kiva.org and Kiva Zip:

1) While Kiva Zip has trustees to provide oversight and guidance for a campaign's execution, Kiva.org has field partners who play a direct and active role by posting campaigns and acting as intermediaries between lenders and borrowers.

2) At Kiva.org, field partners may charge a fee for their services, while in Kiva Zip all funds are transferred directly from lenders to borrowers. Consequently, trustees receive no compensation for their services.

In the following paragraphs we will look at Kiva Zip's operating model in detail.

Kiva Zip is an online platform where lenders make microfinance loans at 0\% interest directly to borrowers via the Internet. The project started in Kenya in November 2011 and in the United States the following month. By the end of 2015, it had provided more than $\$ 11.5$ million in loans in both countries via 11,500 different campaigns, supported by more than 71,500 lenders.

Kiva Zip's crowdlending (peer-to-peer) platform has a social purpose with a model that aims to enhance sustainability through a payback method without interest (unlike a crowd-donating model). Unfortunately, Kiva Zip stopped disbursing new loans in Kenya as of September 2015 since the firm was not reaching the expected repayment rates and was having operating difficulties with trustees and borrowers.

There are three main stakeholders in Kiva Zip:

1. Lenders: these are the individuals or groups providing the financial resources (loans) to make the projects feasible.

2. Trustees: these are individuals or groups responsible for helping the borrowers of their choice who have a potential campaign to post on Kiva Zip. The trustees may help borrowers improve a campaign, refining the content published on Kiva Zip, promoting the campaign among lenders, providing feedback to lenders regarding the execution of their project and providing follow-up on the completion of the stated campaign. The trustees are not liable for nonfulfillment of the campaign objectives, since they receive no payment for their services and act only as support for borrowers.

3. Borrowers: these are individuals who apply for a loan to finance an entrepreneurial project. They are responsible for developing the appeal for funds and, in the event of achieving the funding, for the execution of their projects and for payment to lenders according to the established loan terms.

To obtain a loan, a borrower must prove he or she has a viable entrepreneurial project that will have a positive social impact and that meets certain requirements. Also, to be allowed to appeal for resources on Kiva Zip, a borrower must be endorsed by a trustee or a borrowers' network, with the trustee option being the most common support method. From here on, we will refer to the endorser only as a trustee, since both the trustee and the borrowers' network play the exact same role. If the project is accepted on Kiva Zip (authorized by the platform and endorsed by the

\footnotetext{
${ }^{5}$ Kiva Zip was at https://zip.Kiva.org/, a web address that no longer exists.
} 
trustee), it is first posted privately to the platform and the would-be borrower is required to invite five to 15 lenders if the loan request is for less than $\$ 2,500$ or 15 to 30 lenders if the amount is above that. During the private funding stage, borrowers have to obtain funds from their own personal network and from the network of their trustees. This model provides a peer-pressure control mechanism that is believed to improve repayment rates, since a borrower may be more responsible when it comes to fulfilling a project if the loans come from a person or an institution they know. In addition, it accelerates the funding process.

This private fundraising period lasts 15 days and, if the would-be borrower successfully meets the minimum target, he or she has 45 additional days to raise the remaining amount. (In reality, there were campaigns that were funded over a period of six months, showing that the policy must have been established at some point afterward.) If this goal is not met, then the funds are reimbursed in full to the lenders. Kiva Zip does not allow partial funding of projects, which means that they have to be $100 \%$ funded for any resources to be provided to the would-be borrower. In the industry this is known as "all or nothing" funding, so a campaign creator - in this case, the would-be borrower - "will only receive the pledges that you [the would-be borrower] have accumulated throughout the duration of the campaign if you meet your fundraising goal before the clock winds down." ${ }^{6}$ It is important to note that the maximum loan a borrower may take out is $\$ 10,000$ and the longest payment term is 36 months. If required, borrowers can ask for a grace period of one, two, three or six months, during which they are not obliged to start paying back the loan immediately. This proves quite useful in projects where, due to the nature of the business endeavor, incoming cash flows are not immediate.

An important element of the Kiva Zip model is that 100\% of the resources raised are delivered directly to the borrower at a $0 \%$ interest rate. Therefore, there are no fees or interest payments to hinder the project's feasibility. This may prove useful in understanding the platform's lenders, since they are able to attract users who want to support entrepreneurial endeavors without receiving any extrinsic reward. These lenders may be persuaded by intrinsic objectives, since they are willing to assume all the financial risk without receiving a corresponding fee or interest rate. In most cases (if not all), they may not know the borrower personally but have only the information given on Kiva Zip's website (a short personal story about the would-be borrower.) Lenders contribute to projects through PayPal, a firm that "provides Kiva with free payment processing on all financial transactions." 7 Therefore, borrowers and lenders do not pay fees for any transactions.

Trustees (who may be individuals or organizations) provide a supporting role for borrowers and, to an extent, offer "brand back-up" (which can send a trust signal to would-be lenders) in order to facilitate campaign fundraising. However, trustees are not tied financially to the projects they endorse. Therefore, if a borrower does not pay back the loan, trustees are not obliged to repay the debt still owed.

Kiva Zip maintains and publicizes a record of the repayment rate of projects endorsed by trustees. Therefore, it motivates them to be more rigorous with the projects they support. In addition, Kiva Zip limits the amount of loan requests any one trustee can endorse.

\footnotetext{
${ }^{6}$ http://www.crowdcrux.com/all-or-nothing-vs-flexible-funding-crowdfunding/, last accessed November 2016.

${ }^{7}$ https://borrow.kiva.org/faq, last accessed November 2016.
} 
The platform has a series of complementary controls to increase the likelihood that loans will be repaid. However, Kiva Zip has no way of enforcing payment when a loan payment is late. The controls that Kiva Zip uses include the following: ${ }^{8}$

1. Before the loan has been provided:

a. Screening of would-be borrowers, who are either excluded from the formal financial system or are dedicated to a cause with a social impact.

b. Researching online to verify the identity of the person and the business.

c. Demanding that borrowers have lenders from their own personal network.

d. Requiring trustees to analyze the would-be borrower's campaign.

2. After the loan has been provided:

a. Communicating with borrowers who are late with payments.

b. Monitoring how effective trustees are in ensuring endorsed loans are repaid. When a trustee does not have a positive record on repayment, Kiva Zip may restrict that trustee's future endorsements.

Kiva Zip's management has to make decisions that imply important trade-offs between scalability and control. This means that, in order to increase the number of campaigns, Kiva Zip must acknowledge that it accepts a greater risk of nonpayment or late payments since "many crowdfunding transactions are of small amounts of money," so it would be "impracticable to perform due diligence assessments" (Ibarra Garza et al., 2016).

\subsection{Kiva Zip in Kenya}

Kiva Zip operated its Kenyan endeavor from November 2011 to September 2015. During that time the platform enabled 9,640 crowdlending campaigns, in which 6,621 different would-be borrowers appealed for $\$ 1.8$ million. Borrowers received resources through the M-Pesa mobile payment platform when their campaigns were funded. As stated in the previous section, lenders send money by PayPal transfer.

On September 16, 2015, the Kiva Zip senior director, Jonny Price, said the company had to discontinue operations in Kenya mainly because: 1) the default rate was beyond acceptable levels and 2) the trustees were dissatisfied with the amount of effort required to support projects, which provided no financial benefits for trustees in return. ${ }^{9}$ So, although the loans in the process of being paid back are still active, the organization has had no new campaigns in Kenya since September 2015. The decision to discontinue lending in Kenya was shocking, since the platform was greatly valued by lenders, who funded all but 19 of the 9,640 projects.

\footnotetext{
${ }^{8}$ https://www.kiva.org/about/due-diligence/direct-loans, last accessed November 2016.

9 Jonny Price, “Kiva Zip Pilot in Kenya Winding Down,” Kiva blog, September 16, 2015, https://borrow.kiva.org/blogs/200 (previously at https://zip.Kiva.org/blogs/200), last accessed November 2016.
} 
In the following sections, we will share the methodology used to obtain the data set, the methods used to analyze Kiva Zip's operations in Kenya and the main findings, separated into two sections:

1. Stakeholder analysis: review of campaigns, focusing on the main stakeholders - lenders, trustees and borrowers.

2. Campaign stage analysis: review of campaigns, focusing on the stage of the project - when it is created, when it is being funded or when loans are being repaid.

\section{Methodology}

\subsection{Capturing the Data}

For this study, all the data on Kenya's HTML loan transactions was downloaded from https://zip.Kiva.org/ (which is no longer online) on December 26, 2015. The website today has a different design and content. The data was extracted using the $\mathrm{R}$ software environment and the RCurl and XML packages, which allowed us to develop a code to extract the information stored in the website's source code. The authors followed the data extracting strategies and codes published in Nolan et al. (2014).

The data was collected via web scraping techniques, which allowed us to access the data in an automated and prompt way. Data collection was aided by the fact that Kiva Zip posted each loan using a different URL (web address) and that the loan number was embedded within the URL. Consequently, we developed an algorithm that searched for every loan within a certain range. Once the algorithm found that there was a web address for each specific loan, then our algorithm retrieved the information we set out in detail in Table 3. If a certain web address did not exist, then the instruction was to continue with the next consecutive number.

All data is from campaigns listed in Kenya from November 28, 2011 to September 3, 2015 (the period in which Kiva Zip operated in Kenya) and includes payments made up to December 26, 2015.

On June 2, 2016, Kiva Zip was relabeled Kiva U.S. and began facilitating direct loans (rather than using field partners). With this change, Kiva also modified the overall website, not only in terms of design but also content. Since we knew that the website could be reconfigured at any moment, we decided to download all HTML data on December 26, 2015. This gave us access to all the data that was publicly available on that date, despite the subsequent changes to the website. Our original data is not available in full on the current website. 


\section{Table 3}

Description of the loan set

\begin{tabular}{|c|c|}
\hline Field name & Description \\
\hline id & Transaction identifier. \\
\hline title & Name of loan project. \\
\hline marker & Frequency of loans solicited by the would-be borrower, including the present project. \\
\hline pstory & Biographical information provided by the would-be borrower. \\
\hline bdescription & The would-be borrower's description of the business project. \\
\hline purpose & Specific detail regarding the intended use of the loan. \\
\hline trustee.id & Trustee identifier. \\
\hline \multirow[t]{7}{*}{ state } & $\begin{array}{l}\text { Status of the loan, which can be "ended" (the loan was granted and has been paid back in full), "expired" } \\
\text { (the project was not funded since the intended amount was not raised) or "paying back" (the loan was } \\
\text { granted and the borrower may be paying it back or be in default). }\end{array}$ \\
\hline & From here on, we will use the following terms: \\
\hline & $\begin{array}{l}\text { - "Not funded": those campaigns that expired, meaning they did not raise the target amount of funds. } \\
\text { - "Paid back": those loans that have the status of "ended," meaning that the campaign raised the funds, } \\
\text { the loan was made to the borrower and the borrower paid it back on time. }\end{array}$ \\
\hline & $\begin{array}{l}\text { "On schedule": those loans that were not paid back in full ("paying back") but where there was still } \\
\text { time before the promised date, meaning that the campaign had raised the funds, the loan was made } \\
\text { to the borrower and the borrower had still not paid back the loan in full but had a due date later than } \\
\text { December } 26,2015 \text {, which is when we retrieved the data for all campaigns. }\end{array}$ \\
\hline & $\begin{array}{l}\text { "Late": those loans that have not been paid back in full on the promised date, meaning that the } \\
\text { campaign raised the funds, the loan was made to the borrower and the borrower did not pay back } \\
\text { on time. }\end{array}$ \\
\hline & $\begin{array}{l}\text { "Delinquent": }{ }^{10} \text { those loans that were not paid back in full ("paying back") and were late by less than } \\
\text { six months, meaning that the campaign raised the funds, the loan was made to the borrower, the } \\
\text { borrower had still not paid back the full amount of the loan, which was less than six months late. }\end{array}$ \\
\hline & $\begin{array}{l}\text { "Defaulted": }{ }^{11} \text { those loans that were not paid back in full ("paying back") and were late by six months } \\
\text { or more, meaning that the campaign raised the funds, the loan was made to the borrower, the } \\
\text { borrower had still not paid back the full amount of the loan, which was late by six months or more. }\end{array}$ \\
\hline helps & Short description of the purpose. \\
\hline term & $\begin{array}{l}\text { Number of periods in which the borrower will pay back the loan. A period can be one week, two weeks or } \\
\text { one month. }\end{array}$ \\
\hline grace & $\begin{array}{l}\text { Period during which the borrower is not obliged to start paying back the loan. It may be zero, one, two, } \\
\text { three or six months. }\end{array}$ \\
\hline listed & Date on which the project was uploaded publicly to the platform, in date/time format. \\
\hline disbursed & Date on which the loan is granted and transferred to the borrower. \\
\hline paying.back & Date on which the borrower makes the first payment back to Kiva Zip. \\
\hline industry & The industry that relates to the project, as described by the borrower. \\
\hline years & The borrower's length of experience in the trade. \\
\hline dollar & Dummy for the currency, in U.S. dollars. \\
\hline amount & U.S. dollars required for the loan. \\
\hline location & Location of the borrower, defined by city and country (Kenya for all). \\
\hline lenders & Number of lenders to have funded a campaign. \\
\hline
\end{tabular}

Source: Prepared by the authors based on https://zip.Kiva.org/, last accessed February 2017.

\footnotetext{
${ }^{10}$ This classification is similar to but not the same as that of Kiva Zip. However, we do not have access to information on exactly how late each loan is. For more information, see "How Does Kiva U.S. Manage Delinquency?" (under "Frequently Answered Questions"), Kiva website, https://borrow.kiva.org/faq, last accessed November 2016.

${ }^{11}$ This classification is similar to but not the same as that of Kiva Zip. However, we do not have access to information on exactly how late each loan is. For more information, see Jonny Price, “Important Changes to Kiva Zip's Default Policy," Kiva blog, October 10, 2014, https://borrow.kiva.org/blogs/144, last accessed November 2016.
} 


\subsection{Processing the Data}

The Kiva Zip website was robust, so the 9,640 final observations were complete for each of the fields we downloaded. For further analysis, we performed the following data cleaning activities:

1. There were 183 campaigns overall that had published the size of the loan in the local currency, the Kenyan shilling. Out of these campaigns, the amounts for 167 were converted directly to U.S. dollars while the remaining 16 amounts had to be recoded since the currency amount had been written using ambiguous punctuation to mark thousands and decimals. All currency figures are given in U.S. dollars.

2. Overall, 91 of the campaigns retrieved were located in the United States. However, these were in our preliminary database because the projects had Kenyan contributors. We deleted those 91 campaigns after reviewing them carefully.

3. There were 39 campaigns that appeared twice and one campaign that appeared three times when the currency change was made from Kenyan shillings to U.S. dollars. Therefore, after reviewing them carefully, we eliminated 41 campaigns that were repeats.

When we retrieved the original information, we had 9,772 observations. However, after cleaning, we eliminated 132 observations: 91 because they were not campaigns developed in Kenya and the remaining 41 because they were repeats.

The main areas of opportunity for Kiva Zip are to disclose in detail the situation of those campaigns with "paying back" status since it is not possible to identify which campaigns are on schedule or late with payments or, if late, how much has yet to be repaid. In addition, Kiva Zip does not disclose the amount of debt that has been paid back unless the borrower has paid back the loan in full. To manage this situation, we have assumed that all campaigns are late with payments if they still show "paying back" status after the scheduled date for the final payment.

\subsection{Methods of Analysis}

We start our analysis with descriptive statistics in order to understand better the variables within the vast data set. Since the data set represents the entire population of the loans administered through Kiva Zip in Kenya (all campaigns listed from November 28, 2011 to September 3, 2015 and collected up to December 26, 2015), and not just a sample, descriptive statistics allow us to understand Kiva Zip in Kenya entirely. In addition, we engage in a qualitative discussion of relevant aspects that arise during the quantitative analysis. This article is aimed at exploring the prosocial crowdfunding phenomenon and not at developing and testing hypotheses. Therefore, the exploratory analysis may provide insight for a better understanding of prosocial crowdlending, peer-to-peer lending, alternative financing activities in a low-income country and small entrepreneurial ventures, among other relevant topics. 


\section{Stakeholder Analysis}

\subsection{Lenders}

Lenders are those individuals or groups that provide the financial resources (funds) so that the projects may be developed. It is obvious that, without lenders, there would be no borrowers interested in the platform. Therefore, it is important to analyze carefully the lenders' characteristics and how these relate to the success of Kiva Zip. A crowdfunding platform such as Kiva Zip will benefit from what is considered the "network effect" (Shapiro and Varian, 1999), since the value of the platform increases as the number of borrowers and lenders interacting increases.

Kiva Zip listed its first campaign in Kenya in November 2011 and in the United States in December 2011. Subsequently, there were more than 11,500 campaigns (asking for \$11.5 million), backed by close to 73,000 lenders. What is surprising about these figures is that lenders assume $100 \%$ of the risk of the resources provided and do not receive a premium for the uncertainty of whether or not they will get their money back. These facts demonstrate an external aspect of lender behavior, which would send a strong message to Kiva Zip's executives so they could understand that lenders in Kiva Zip might behave more like donors than lenders.

In Kenya, the lenders funded all but 19 of the 9,640 listed campaigns. What is characteristic of Kiva Zip in Kenya is the small amount of the loans. The median amount of a funded campaign was $\$ 125$ and the average was \$191. (In the case of Kiva.org, from 2005 to 2015, the median loan in Kenya was for $\$ 500$ and the average for $\$ 779$ [N'Guessan et al., 2016].) Consequently, there is only a small number of lenders per campaign: a median of nine and an average of 11 . The smallest number of lenders per funded campaign was one and the highest was 85 . Of all funded campaigns, 30\% had five lenders or fewer and 76\% had 15 or fewer.

\section{Table 4}

Concentration of lenders per campaign

\begin{tabular}{lc}
\hline Lenders per campaign & Campaigns \\
\hline 0 (not funded) & 19 \\
1 & 494 \\
2 to 5 & 2,430 \\
6 to 10 & 2,591 \\
11 to 15 & 1,810 \\
16 to 20 & 929 \\
21 to 25 & 542 \\
26 to 30 & 356 \\
$>30$ & 469 \\
Total & 9,640 \\
\hline
\end{tabular}

Source: Prepared by the authors based on https://zip.Kiva.org/, last accessed February 2017.

In addition to the number of lenders, it would be useful to understand the contribution that each lender made to each campaign. Unfortunately, Kiva Zip does not disclose the amount of each lender's loan but only the number of lenders per campaign. The 109,910 lenders (not unique 
lenders but aggregated ones) funded $\$ 1,837,351$ in total, giving an average contribution of $\$ 16.72$. The most money a lender could have provided to an individual campaign was $\$ 900$ (in the case of the largest funded campaign, which had six lenders). Therefore, lenders are not exposed to high risk based on the size of individual loans.

However, the risk may be also be measured by the number of campaigns a lender has funded, which, in this case, unfortunately we do not know. Consequently, the repayment level takes on vital importance. Kiva Zip has argued that lenders may decrease their exposure to risk by diversifying their loan portfolio, ${ }^{12}$ which would indeed decrease their exposure but, on the other hand, it would also dilute their individual investments to the point where "supporters [lenders] will not pursue most of those kinds of breaches because of lack of interest; this is due to the fact that most supporters will have transferred relatively small amounts of money" (Ibarra Garza et al., 2016). The invested amount will be so small that any legal pursuit will be more costly than the loan itself.

Kiva.org has a repayment rate of $97.2 \% .{ }^{13}$ (Repayment is defined as when a campaign is funded and the loan is paid back in full.) Therefore, it is natural that such a high standard could create a certain expectation that the operations of Kiva Zip in Kenya could not meet. While repayment is critical for the sustainability of a crowdlending platform, it is important to analyze how sensitive the lenders of Kiva Zip may be to repayment rates. Since the degree of lateness is not known, as stated in Table 3, we defined as "late" a loan that is not paid back in full by the promised date, as "delinquent" a loan that is late by less than six months and as "defaulted" a loan that is late by six months or more. In this case, $17.21 \%$ of the funded campaigns were late with payments and consequently Kiva Zip decided to discontinue loans in Kenya. However, is a 17\% late payment rate such a bad scenario for lenders?

1) As mentioned above, lenders assume all risk and are paid no interest, which may indicate that monetary incentives must not be their top priority. This does not mean that lenders want to lose their money but that they would be accepting of a loss or the risk of late loan payments in return for the satisfaction of supporting particular social entrepreneurial projects.

2) Perhaps some of Kiva Zip's lenders prefer to help projects in Kenya rather than those in the United States. (Kiva Zip is currently available only in the United States and under the name "Kiva U.S."). For example, in Kenya less than 1\% of the listed campaigns went unfunded, while in the United States it was $10 \% .{ }^{14}$ Kenya is a country that can benefit most from a platform such as Kiva Zip, since it has an annual per capita GDP of $\$ 1,358$, a poverty rate of $43.4 \%$ of the population and an illiteracy rate of $22 \%$ of the population above 15 years old. The United States has per capita GDP of $\$ 54,630$, a poverty rate of $15.1 \%$ and an illiteracy rate of $14 \% .^{15}$

\footnotetext{
${ }^{12}$ https://www.kiva.org/about/due-diligence/risk, last accessed November 2016.

13 "Kiva by the Numbers," Kiva website, https://www.Kiva.org/about/stats, accessed September 27, 2016.

${ }^{14}$ This was the Kiva U.S. claim on its advertisement on Google AdWords but, when clicking on the link, we could not verify this statistic on the Kiva U.S. website ("Grow Your Business With Kiva," http://us.kiva.org/borrow/?gclid=CNemzsPyr88CFYVAGwodPhwOHA), last accessed November 2016.

${ }^{15} \mathrm{http}$ ://data.worldbank.org/indicator/NY.GDP.PCAP.CD http://www.indexmundi.com/g/r.aspx?v=69 https://www.cia.gov/library/publications/the-world-factbook/fields/2103.html http://www.huffingtonpost.com/2013/09/06/illiteracy-rate_n_3880355.html, last accessed November 2016.
} 
Kiva Zip has a bulletin board on its website ${ }^{16}$ where the firm shares important messages for the community. Below message 200 ("Kiva Zip Pilot in Kenya Winding Down"), ${ }^{17}$ there are multiple complaints from lenders, sharing their dissatisfaction at Kiva Zip discontinuing operations in Kenya and sometimes giving an insight into their own motivations. The following are just a few examples:

1) "I don't understand the decision to shut down the Kenyan program."

2) "Kiva Zip's dropping of the Kenya program is very disappointing."

3) "Most of the reasons I had chosen to loan exclusively through Zip - the ability to make small loans (as low as \$5) to impoverished entrepreneurs in Africa - have been removed. [...] Kenya needs your help Zip - what about it?”

4) "Hoping that Kiva Zip in Kenya will be reinstated. It's amazing how much value our dollar has in a country like Kenya."

These comments, although subjective and possibly unrepresentative, may indicate the attitude of Kiva Zip's lenders toward alleviating poverty.

At the moment, we have no data to prove the validity of these beliefs, but further research on the following topics could be relevant for an understanding of prosocial crowdlending and specifically the Kiva Zip community:

1) The characteristics of a project's lenders

2) The origin of lenders

3) The proportion of new lenders per project

4) The repayment impact on lenders

\subsection{Trustees}

Kiva Zip defines trustees as those who "source entrepreneurs they believe in and publicly endorse them as borrowers on the Kiva website. Trustees have no financial liability for loans, but their reputation is tied to the repayment rate of the borrowers they endorse. Unlike Field Partners, Trustees never actually handle the loans, which Kiva disburses directly to the borrowers. Trustees can be individuals or organizations." ${ }^{18}$ Although trustees have an important role on the platform, it seems that they will never have the same responsibility or commitment as the field partners on Kiva.org. Nevertheless, the better the trustees carry out their activities, the less delinquency and defaulting there should be with the endorsed loans.

Kiva Zip has a diverse network of trustees, which has allowed the organization to avoid the risk of concentrating many loans on a few sponsors. In Kenya, the 9,640 campaigns were endorsed (which means that the borrower was supported in nonfinancial ways) by 506 different trustees, none of whom was involved in more than $4 \%$ of all campaigns. Of those 506 trustees, 122 were

\footnotetext{
${ }^{16}$ In the previous version of the website, blog posts were stored at https://zip.kiva.org/blogs/. Today those posts are stored at the following URL: https://borrow.kiva.org/blogs, last accessed November 2016.

${ }^{17}$ Jonny Price, “Kiva Zip Pilot in Kenya Winding Down,” Kiva blog, September 16, 2015, https://borrow.kiva.org/blogs/200 (previously at https://zip.kiva.org/blogs/200), last accessed November 2016.

18 “Our Trustees," Kiva website, https://www.kiva.org/trustees, last accessed November 2016.
} 
individuals and 384 were organizations. On Kiva.org, 40 partners managed more than 63,000 loans in Kenya from 2005 to 2015 (N’Guessan et al., 2016).

\section{Table 5}

Endorsed campaigns by trustee

\begin{tabular}{lcccc}
\hline $\begin{array}{l}\text { \# of endorsed } \\
\text { campaigns }\end{array}$ & $\begin{array}{c}\text { \# of } \\
\text { trustees }\end{array}$ & $\begin{array}{c}\text { Total } \\
\text { campaigns }\end{array}$ & $\begin{array}{c}\text { Late-paying } \\
\text { campaigns }\end{array}$ & $\begin{array}{c}\text { Lateness } \\
\text { rate }\end{array}$ \\
\hline 1 & 30 & 30 & 10 & $33 \%$ \\
2 to 5 & 56 & 186 & 54 & $29 \%$ \\
6 to 10 & 285 & 2,716 & 525 & $19 \%$ \\
11 to 15 & 23 & 287 & 69 & $24 \%$ \\
16 to 20 & 31 & 565 & 92 & $16 \%$ \\
21 to 25 & 11 & 251 & 53 & $21 \%$ \\
26 to 30 & 14 & 393 & 80 & $20 \%$ \\
31 to 35 & 4 & 133 & 23 & $17 \%$ \\
$>35$ & 52 & 5,060 & 750 & $15 \%$ \\
Total & 506 & 9,621 & 1,656 & $17 \%$ \\
\hline
\end{tabular}

Source: Prepared by the authors based on https://zip.Kiva.org/, last accessed February 2017.

One issue regarding the number of projects per trustee (median 10.00 and mean 19.05) can be observed by analyzing the distribution of projects per trustee, taking into account the tenure of each trustee on Kiva Zip. The first 253 trustees that sponsored borrowers account for 7,151 loans (74\% of all campaigns) while the remaining (and following) 253 trustees are responsible for 2,489 loans. This may not be positive for Kiva Zip, since it makes evident that "younger" trustees have not developed a scale of support for projects as the "older" users have (although we must recognize that trustees with longer tenures have had more time to sponsor campaigns). The first trustee to sponsor Kenyan campaigns was registered on Kiva Zip on November 20, 2011, and the last one on April 15, 2015. There is no strong evidence of trustee attrition since 271 trustees (54\% of the total) were still providing loans in 2015.

The trustees were involved in Kiva Zip to strengthen borrowers' projects and to help with publicity and fundraising. However, the task of fundraising is compromised when trustees endorse projects that are unsuccessful.

Although it is intuitive to believe that trustees who endorse more projects will also have more late-paying campaigns, the lateness rate decreases (on average) as trustees manage more campaigns. We can see in Table 5 that $53 \%$ of the campaigns $(5,060$ out of 9,021) were managed by trustees who endorsed 36 or more projects, while they had $45 \%$ of the late-paying campaigns (750 out of 1,656). On the other hand, those trustees who managed 35 projects or fewer account for $47 \%$ of all campaigns $(4,561$ out of 9,021) but 55\% of the late-paying campaigns (906 out of 1,656). This may provide us with insight into the impact of the scalability of trustees' operations on the successful repayment of loans. 


\section{Table 6}

Trustees with the most late-paying loans

\begin{tabular}{lcccc}
\hline Trustee ID & $\begin{array}{c}\text { \# of funded } \\
\text { campaigns }\end{array}$ & $\begin{array}{c}\text { Late-paying } \\
\text { campaigns }\end{array}$ & $\begin{array}{c}\text { Lateness } \\
\text { rate }\end{array}$ & $\begin{array}{c}\text { \% of all late-paying } \\
\text { campaigns }\end{array}$ \\
\hline 63 & 329 & 69 & $21 \%$ & $4 \%$ \\
220 & 134 & 58 & $43 \%$ & $4 \%$ \\
536 & 159 & 45 & $28 \%$ & $3 \%$ \\
776 & 125 & 40 & $32 \%$ & $2 \%$ \\
309 & 239 & 37 & $15 \%$ & $2 \%$ \\
859 & 149 & 37 & $25 \%$ & $2 \%$ \\
834 & 153 & 34 & $22 \%$ & $2 \%$ \\
250 & 138 & 31 & $22 \%$ & $2 \%$ \\
68 & 133 & 30 & $23 \%$ & $2 \%$ \\
232 & 219 & 29 & $13 \%$ & $2 \%$ \\
Total & 1,778 & 410 & $23 \%$ & $25 \%$ \\
\hline
\end{tabular}

Source: Prepared by the authors based on https://zip.Kiva.org/, last accessed February 2017.

We can see that there are late payments for $18 \%$ of all loans $(1,778$ out of 9,621) and in addition that the 10 trustees with the highest number of late-paying campaigns accounted for $25 \%$ of all delays $(410$ out of 1,656$)$. This again shows us that scale is not necessarily what explains the lateness rate but specifically the quality of the trustees' work.

Further research should be done into the efficacy of or need for the trustee figure in order to understand whether endorsement by trustees helps borrowers to be more reliable and gives lenders a signal of trustworthiness in order to help project fundraising.

\subsection{Borrowers}

The borrowers are arguably the most important stakeholder on the Kiva Zip platform since they are in charge of creating campaigns, raising funds, executing their project and paying back the loans. The most active role on the platform is, without a doubt, played by the borrowers.

\section{Table 7}

Number of loans per borrower

\begin{tabular}{lcr}
\hline Number of loans & Borrowers & $\%$ \\
\hline 1 & 4,696 & $71 \%$ \\
2 & 1,139 & $17 \%$ \\
3 & 542 & $8 \%$ \\
4 & 186 & $3 \%$ \\
5 & 53 & $1 \%$ \\
6 & 4 & $0 \%$ \\
7 & 1 & $0 \%$ \\
Total & 6,621 & $100 \%$ \\
\hline
\end{tabular}

Source: Prepared by the authors based on https://zip.Kiva.org/, last accessed February 2017. 
As seen in Table 7, the 9,640 campaigns were created by 6,621 different borrowers. This may have allowed Kiva Zip to have a diverse base of borrowers and consequently decrease any risk associated with the concentration of projects. Nevertheless, this volume of borrowers also complicates Kiva Zip's control regarding the detection of fraudulent campaigns, unpromising projects and irregularities with borrowers. Although Kiva Zip does perform due diligence on campaigns, scalability compromises quality and control.

Another important aspect of the borrowers is the experience they have in their trade. When they create a campaign, they must select the industry in which their project will take place and in addition state how much specific experience they have. Although experience is self-reported, $86 \%$ of borrowers claim to have one year or more of experience in the business in which they will use their funds and, more importantly, 34\% of them say they have more than five years of experience. This may prove useful, since experience may make the borrowers' more skilled at developing campaigns and executing them successfully. For example, campaigns where the borrower has no experience in the trade (it is a new business) have a late-payment rate of 36\% while, when the borrower has more than five years of experience, the rate decreases to $15 \%$. This may encourage Kiva Zip to promote experience as an important factor for funding campaigns (and also to promote the campaigns themselves on the website).

Paradoxically, campaigns where the borrower has less experience in the trade (one year or less) are funded, on average, in fewer days (considering payment terms and grace days) than campaigns where they have more experience (more than one year). Several factors may cause this funding behavior among lenders, who may be inclined to help new businesses or borrowers who have decided to pursue an entrepreneurial venture. In addition, in the case of new business campaigns, would-be borrowers promise to pay back the loan within 124 days on average while it is 131 days for businesses where would-be borrowers have more than five years of experience.

These descriptive statistics allow us to reinforce how centrally important the borrower is to the success of campaigns and consequently of Kiva Zip.

\section{Table 8}

Borrowers' experience in the trade of funded campaigns

\begin{tabular}{lcccccc}
\hline $\begin{array}{l}\text { Borrower's } \\
\text { experience }\end{array}$ & Campaigns & $\begin{array}{c}\text { \% of } \\
\text { campaigns }\end{array}$ & $\begin{array}{c}\text { Defaulted } \\
\text { campaigns }\end{array}$ & $\begin{array}{c}\text { Default } \\
\text { rate }\end{array}$ & $\begin{array}{c}\text { Average } \\
\text { days to } \\
\text { fund }\end{array}$ & $\begin{array}{c}\text { Average } \\
\text { length } \\
\text { (days) }\end{array}$ \\
\hline New Business & 196 & $2 \%$ & 71 & $36 \%$ & 14.8 & 124.4 \\
< 6 months & 221 & $2 \%$ & 39 & $18 \%$ & 14.3 & 107.2 \\
6 months to 1 year & 885 & $9 \%$ & 149 & $17 \%$ & 14.5 & 113.2 \\
1 year to 3 years & 2,831 & $29 \%$ & 534 & $19 \%$ & 17.4 & 128.9 \\
3 years to 5 years & 2,218 & $23 \%$ & 383 & $17 \%$ & 20.2 & 127.3 \\
$>$ 5 years & 3,270 & $34 \%$ & 480 & $15 \%$ & 22.4 & 130.7 \\
Total & 9,621 & $100 \%$ & 1,656 & $17 \%$ & 19.4 & 127.1 \\
\hline
\end{tabular}

Source: Prepared by the authors based on https://zip.Kiva.org/, last accessed February 2017. 


\section{Campaign Stage Analysis}

\subsection{Campaign Creation}

Kiva Zip's relevance depends mainly on it attracting two separate stakeholders: lenders and borrowers. As in industries that benefit from strong network effects, Kiva Zip needs to have relevant projects to attract lenders and enough borrowers to attract funds.

The platform's success will depend on how deeply the organization understands the critical success factors that help in the availability of campaigns, their funding and repayment to lenders. If these three main aspects are studied in detail, Kiva Zip could adjust its value proposal and even become more relevant and sustainable within the crowdfunding industry or, more specifically, the prosocial crowdlending industry.

\section{Table 9}

Kiva Zip Kenya listed projects by year

\begin{tabular}{lccc}
\hline Year & Listed campaigns & Funds requested & Average amount \\
\hline 2011 (Nov.-Dec.) & 16 & 6,675 & 417 \\
2012 & 363 & 71,034 & 196 \\
2013 & 1,078 & 188,027 & 174 \\
2014 & 4,718 & 877,727 & 186 \\
2015 (Jan.-Sept.) & 3,465 & 699,112 & 202 \\
Total & 9,640 & $1,842,576$ & 191 \\
\hline
\end{tabular}

Source: Prepared by the authors based on https://zip.Kiva.org/, last accessed February 2017.

From January 1 to September 3, 2014, there were 2,296 loans but, in the same period of 2015, there were 3,465 loans. The last year of operations in Kenya, 2015, could have had more loans than 2014 if the organization had continued operations for the full year. In total, $\$ 1,842,576$ was requested through the 9,640 campaigns. Dividing the resources by the number of campaigns gives an average of more than $\$ 191$ raised per campaign. On Kiva.org Kenya, from 2005 to 2015, 63,500 campaigns were funded to the tune of more than $\$ 33$ million. 


\section{Table 10}

Listed campaigns by industry

\begin{tabular}{lccccc}
\hline Campaign industry & $\begin{array}{c}\text { \# of } \\
\text { campaigns }\end{array}$ & $\begin{array}{c}\text { Average } \\
\text { amount } \\
\text { requested }\end{array}$ & $\begin{array}{c}\text { Average } \\
\text { days to } \\
\text { fund }\end{array}$ & $\begin{array}{c}\text { Length of } \\
\text { loan (days) }\end{array}$ & $\begin{array}{c}\text { Amount } \\
\text { funded per } \\
\text { day (\$) }\end{array}$ \\
\hline Agriculture & 1,927 & 156 & 23 & 114 & 6.68 \\
Food stall/grocery store & 1,667 & 187 & 17 & 127 & 10.95 \\
Clothing/jewelry/accessories & 1,564 & 196 & 19 & 131 & 10.27 \\
Retail - general & 1,234 & 199 & 21 & 131 & 9.60 \\
Services & 870 & 201 & 18 & 131 & 11.43 \\
Other & 796 & 194 & 20 & 126 & 9.59 \\
Beauty/cosmetics & 533 & 186 & 21 & 122 & 8.78 \\
Arts/crafts & 246 & 220 & 12 & 145 & 19.10 \\
Energy & 231 & 258 & 14 & 148 & 18.14 \\
Healthcare & 167 & 288 & 11 & 160 & 25.96 \\
Transportation & 164 & 221 & 17 & 134 & 13.25 \\
Retail - wholesale & 126 & 203 & 16 & 130 & 12.75 \\
Housing/construction & 115 & 227 & 20 & 136 & 11.36 \\
Total & 9,640 & 191 & 19 & 127 & 9.88 \\
\hline
\end{tabular}

Source: Prepared by the authors based on https://zip.Kiva.org/, last accessed February 2017.

Kiva Zip defined a set of 24 different industries and an additional "other" category to classify the trade of a campaign. However, in Kenya there were campaigns from only 13 industries (including "other"). The classification is self-reported by the borrower.

The categories of agriculture, food stall/grocery store, clothing/jewelry/accessories, retail - general, and services represent 75\% of the total number of campaigns, 75\% of all defaulted projects and 73\% of the money requested. Of those five industries, retail - general has the lowest late-payment rate (13\%), while the highest belongs to the food stall and grocery store category (21\%). Although healthcare accounts for only $2 \%$ of all campaigns, it has an excellent latepayment rate of only $7 \%$. This statistic is low considering the overall $17 \%$ late-payment rate.

On all of Kiva.org, the top five industries from 2005 to 2015 were (in descending order): food, retail, agriculture, clothing and services. These five industries, in an order similar to that on Kiva Zip, represent 89.8\% of all campaigns (N'Guessan et al., 2016). 


\section{Table 11}

Number of listed campaigns and requested funds by day of the week

\begin{tabular}{|c|c|c|c|c|c|c|c|c|c|c|c|c|}
\hline \multirow[b]{2}{*}{ Day of the week } & \multicolumn{2}{|c|}{2011} & \multicolumn{2}{|c|}{2012} & \multicolumn{2}{|c|}{2013} & \multicolumn{2}{|c|}{2014} & \multicolumn{2}{|c|}{2015} & \multicolumn{2}{|c|}{ Total } \\
\hline & $\#$ & $\$$ & $\#$ & $\$$ & $\#$ & $\$$ & $\#$ & $\$$ & \# & $\$$ & $\#$ & $\$$ \\
\hline Sunday & & & 20 & 1,225 & 17 & 2,448 & 86 & 16,820 & 50 & 6,250 & 173 & 26,744 \\
\hline Monday & 1 & 350 & 75 & 9,425 & 115 & 20,523 & 879 & 157,039 & 402 & 79,148 & 1,472 & 266,486 \\
\hline Tuesday & 2 & 250 & 86 & 17,734 & 237 & 45,500 & 739 & 144,906 & 789 & 166,675 & 1,853 & 375,065 \\
\hline Wednesday & 13 & 6,075 & 42 & 11,900 & 296 & 46,594 & 1,097 & 190,343 & 587 & 121,140 & 2,035 & 376,052 \\
\hline Thursday & & & 56 & 9,400 & 245 & 44,600 & 927 & 178,706 & 735 & 134,525 & 1,963 & 367,231 \\
\hline Friday & & & 53 & 14,100 & 157 & 26,362 & 913 & 172,288 & 741 & 165,848 & 1,864 & 378,598 \\
\hline Saturday & & & 31 & 7,250 & 11 & 2,000 & 77 & 17,625 & 161 & 25,525 & 280 & 52,400 \\
\hline Total & 16 & 6,675 & 363 & 71,034 & 1,078 & 188,027 & 4,718 & 877,727 & 3,465 & 699,112 & 9,640 & $1,842,576$ \\
\hline
\end{tabular}

Source: Prepared by the authors based on https://zip.Kiva.org/, last accessed February 2017. 
During the first two years of operations (from November 2011 to October 2013), there were 1,186 campaigns, which requested $\$ 216,056$. However, in the final two years or so (from November 2013 to September 2015), there were 8,454 campaigns, which requested $\$ 1,626,520$ in funding. This increase represents a 613\% increase in the total number of campaigns, or growth of 652\% in the total funds requested.

The listing of campaigns by the day of the week shows us that most activity is concentrated on regular workdays: Monday through Friday account for 95\% of all listings and 96\% of all requested funds. Although we do not have primary data to identify the reason for this behavior, we assume that, on regular workdays, borrowers receive help from trustees or others to upload campaigns. In addition, we hypothesize that borrowers may upload campaigns at work, where they have access to the Internet. This assumption fits in with studies that show that people in Kenya access the Internet using mainly mobile devices and/or workplace computers. ${ }^{19}$

Over the four years of operations in Kenya, most days (91\% of them) listed fewer than 50 campaigns. $^{20}$ However, between August 5, 2014, and February 9, 2015, there were 3,546 campaigns, representing 37\% of all campaigns created with Kiva Zip Kenya. The day with the most activity was November 12, 2014, with 243 campaigns, which amazingly had only 26 defaults (an 11\% default rate) and 10 of those defaults related to the same trustee. This extraordinary growth in activity was fueled by a partnership between Kiva Zip and Joyful Women Organization (JoyWo). ${ }^{21}$ The latter organization aims to help women through a group funding method known as "table banking," where the members of a group save and receive loans under the guidance of a "chairlady." Although JoyWo already had a successful model for providing an alternative financial solution for low-income people, Kiva Zip represented a powerful complementary solution for both parties: JoyWo brings to the table a community that seeks financial growth through a model with social participation (and control) and Kiva Zip brings a platform that allows those same people to raise funds from an international crowd. We have determined that JoyWo enabled 748 campaigns, only one of which was not funded, but $21.65 \%$ of the campaigns had late payments, which is higher than the overall average rate of $17 \%$.

\footnotetext{
${ }^{19}$ http://www.ipsos.co.ke/spr/downloads/downloads.php?dir=media_research\&file=Media\%20Consumption\%20Habits \%20in\%20Kenya\%20.pdf, last accessed November 2016.

${ }^{20}$ Counting as a day when at least one campaign was listed.

${ }^{21}$ https://borrow.kiva.org/blogs/149, https://borrow.kiva.org/blogs/191 and http://blog.kiva.org/faqs/joywo, last accessed November 2016.
} 


\section{Table 12}

Number of listed campaigns and requested funds by month of the year ${ }^{22}$

\begin{tabular}{|c|c|c|c|c|c|c|c|c|c|c|c|c|}
\hline \multirow[b]{2}{*}{ Month } & \multicolumn{2}{|c|}{2011} & \multicolumn{2}{|c|}{2012} & \multicolumn{2}{|c|}{2013} & \multicolumn{2}{|c|}{2014} & \multicolumn{2}{|c|}{2015} & \multicolumn{2}{|c|}{ Total } \\
\hline & $\#$ & $\$$ & $\#$ & $\$$ & $\#$ & $\$$ & $\#$ & $\$$ & $\#$ & $\$$ & $\#$ & $\$$ \\
\hline January & - & - & & & 44 & 3,700 & 213 & 39,498 & 511 & 83,850 & 768 & 127,048 \\
\hline February & - & - & 12 & 6,850 & 15 & 1,700 & 203 & 45,747 & 352 & 74,895 & 582 & 129,192 \\
\hline March & - & - & 24 & 5,900 & 65 & 10,825 & 274 & 58,572 & 560 & 127,925 & 923 & 203,222 \\
\hline April & - & - & 30 & 15,975 & 97 & 18,100 & 255 & 50,147 & 259 & 56,750 & 641 & 140,972 \\
\hline May & - & - & 11 & 3,550 & 53 & 7,700 & 317 & 60,789 & 376 & 83,348 & 757 & 155,387 \\
\hline June & - & - & 89 & 11,134 & 51 & 7,200 & 303 & 57,289 & 440 & 94,075 & 883 & 169,698 \\
\hline July & - & - & 22 & 5,300 & 104 & 24,225 & 246 & 50,005 & 655 & 108,523 & 1,027 & 188,053 \\
\hline August & - & - & 4 & 1,725 & 96 & 18,650 & 456 & 91,431 & 296 & 65,645 & 852 & 177,451 \\
\hline September & - & - & 52 & 7,200 & 106 & 14,722 & 566 & 101,542 & 16 & 4,100 & 740 & 127,563 \\
\hline October & - & - & 5 & 650 & 176 & 31,525 & 916 & 152,317 & - & - & 1,097 & 184,492 \\
\hline November & 8 & 2,075 & 45 & 5,675 & 161 & 26,519 & 621 & 106,846 & - & - & 835 & 141,115 \\
\hline December & 8 & 4,600 & 69 & 7,075 & 110 & 23,162 & 348 & 63,545 & - & - & 535 & 98,382 \\
\hline Total & 16 & 6,675 & 363 & 71,034 & 1,078 & 188,027 & 4,718 & 877,727 & 3,465 & 699,112 & 9,640 & $1,842,576$ \\
\hline
\end{tabular}

Source: Prepared by the authors based on https://zip.Kiva.org/, last accessed February 2017.

\footnotetext{
${ }^{22}$ Operations started in November 2011 and ended in September 2015

24 - IESE Business School-University of Navarra
} 
Although Kiva Zip operated in Kenya in five different calendar years, only three of those years had operations for the full year, which makes it more difficult to identify any possible seasonal factors affecting the listing of campaigns. For example, July (month 7) represented an increase over June in 2013 and 2015 but a decrease for 2012 and 2014, while there are no such data for 2011. Similar unpatterned behavior can be seen in other months, such as April, June and December.

\subsection{Campaign Funding}

As already mentioned, of the 9,640 projects, only 19 were not funded. This statistic cannot be overstated as it is strong evidence of the confidence that lenders had in the borrowers, the trustees and Kiva Zip.

Since only 19 projects were not funded, we decided to analyze those 19 in depth:

- While 69\% of all campaigns were first-time loans for a would-be borrower, $74 \%$ of expired campaigns (those not funded) were first-time loans.

- The 19 unfunded campaigns were endorsed by nine different trustees, although 12 of the 19 campaigns (63\%) were endorsed by three trustees.

- $16 \%$ of unfunded campaigns were those of would-be borrowers who had between one year and three years of experience. (These would-be borrowers accounted for $29 \%$ of all campaigns.)

- $100 \%$ of the unfunded campaigns were listed in 2014, which is surprising since this year accounts for 49\% of all campaigns. Specifically, October 2014 had 15 of the 19 unfunded campaigns and, within that month, October 29 had 11 of them.

- $\quad 42 \%$ of the unfunded campaigns were classified as belonging to the industrial category "retail - general," even though this industry represents only 13\% of all campaigns.

- Projects requested \$191 on average (median \$125). However, the 19 projects that were not funded requested $\$ 275$ on average (median $\$ 125$ ).

- Overall, 46 campaigns requested $\$ 800$ or more. Those campaigns represented less than $1 \%$ of all campaigns. Only two of those 46 campaigns were not funded.

- 228 campaigns had a loan length of one year or more. Only one of those campaigns was not funded.

- Borrowers may pay back loans at three different payment frequencies: every week, every two weeks or every month (for a certain number of periods). Of the 9,640 campaigns, $65 \%$ had weekly payments, $1 \%$ fortnightly and 34\% monthly. Surprisingly, all the campaigns with fortnightly payments were funded, five of the 19 unfunded campaigns proposed weekly payments and the remaining 14 were for loans where the payments would be monthly. This means that monthly payments account for $34 \%$ of all campaigns but represent 74\% of the unfunded campaigns. This may signal a preference among borrowers for making more frequent and short-term payments.

The correlation between the number of days each project took to be funded (days to fund) and the amount requested is 0.01 , which is too weak to give an indication as to whether more "expensive" projects would take more days to fund on this platform. 
The median time for funding loans is 11.72 days. Some loans were funded immediately but others took 183 days to secure funding (of those that did get funded). Surprisingly, 78\% of all projects were funded in less than 30 days. Added to the fact that $99.8 \%$ of all projects were funded, this shows that the demand for projects was greater than the campaign offer. Therefore, Kiva Zip could have found an alternative to let it maintain its operations in Kenya.

Although Kiva Zip benefits from having more campaigns on its platform, would-be borrowers may dislike there being a higher number of competing campaigns since these other would-be borrowers may attract attention and ultimately the desired funds to them. The median of competitors for every listed campaign was 421 , so borrowers really had to make an effort to shine among a lot of competing campaigns. The correlation between the number of listed campaigns per month and the average days taken to fund the campaigns listed in that month is 0.43 . This indicates that, as more campaigns were posted, it took longer to fund them, which could reduce the likelihood of success of an entrepreneur since some business ventures may have a window of opportunity that later expires. This relation was most evident in 2013.

\section{Table 13}

Descriptive statistics of campaign funding

\begin{tabular}{lccrrr}
\hline Variable & Observations & Average & Median & Minimum & Maximum \\
\hline Requested amount & 9,640 & $\$ 191$ & $\$ 125$ & $\$ 20$ & $\$ 900$ \\
Length of loan (days) $^{23}$ & 9,640 & 127 & 91 & 21 & 1,095 \\
Grace days & 9,640 & 1 & 0 & 0 & 61 \\
Days to raise funding & 9,621 & 19 & 12 & 0 & 183 \\
Competing campaigns & 9,640 & 636 & 421 & 0 & 5,347 \\
\hline
\end{tabular}

Source: Prepared by the authors based on https://zip.Kiva.org/, last accessed February 2017.

This prosocial crowdlending platform proved to be a successful alternative for many borrowers. However, success could be defined in two different ways: first as when a campaign secures funding and second as when a loan is paid back on time. We know that funds were raised on Kiva Zip Kenya for all but 19 of the listed campaigns, so the definition of success may shift from being funded to how quickly a campaign receives the funds.

Consequently, the "days to fund" variable (the days it took a campaign to raise 100\% of the funds after it was listed officially on Kiva Zip) may become a variable with strategic importance for the platform. If Kiva Zip manages to collect funds more quickly, it may enable borrowers to execute their campaigns immediately and also make Kiva Zip a preferred option for quick and affordable financing, which is attractive to borrowers.

The correlation between days to fund and length of loan (how many days it will take the borrower to pay back the loan to the lender) is surprisingly weak (0.03). The requested amount and days to fund also have a weak correlation (0.01).

\footnotetext{
${ }^{23}$ Including grace days.
} 
However, competing campaigns and days to fund have a strong positive correlation, in this case 0.84. This result seems intuitive since it will take a specific campaign more time to raise the resources it needs when there are more campaigns competing against it for funding. Kiva Zip's management should address this relationship carefully since a greater number of campaigns may make it easier to attract lenders but it also may affect how likely it is that a specific campaign will secure funding and how quickly it will do so.

Finally, an in-depth understanding of the variables that affect campaign funding may be useful for Kiva Zip. This knowledge could help the firm decide how to filter and promote campaigns. Nowadays, Kiva Zip (under the brand "Kiva U.S.") has a landing page where the default option is "Trending Now," where certain campaigns are promoted. Unfortunately, this discriminating algorithm is not fully disclosed.

\section{Table 14}

Correlation matrix

\begin{tabular}{lccccc}
\hline & $\begin{array}{c}\text { Requested } \\
\text { amount }\end{array}$ & $\begin{array}{c}\text { Length of } \\
\text { loan }\end{array}$ & $\begin{array}{c}\text { Grace } \\
\text { days }\end{array}$ & $\begin{array}{c}\text { Days to } \\
\text { fund }\end{array}$ & $\begin{array}{c}\text { Competing } \\
\text { campaigns }\end{array}$ \\
\hline Requested amount & 1.00 & & & & \\
Length of loan & 0.80 & 1.00 & & & \\
Grace days & -0.04 & 0.02 & 1.00 & 1.00 & 1.00 \\
Days to fund & 0.01 & 0.03 & -0.01 & 0.84 & 0.04 \\
Competing campaigns & -0.06 & -0.05 & & & \\
\hline
\end{tabular}

Source: Prepared by the authors based on https://zip.Kiva.org/, last accessed February 2017.

It is inevitable to relate the days it takes to fund a campaign to the loan amount and the length of time to pay it back. We developed an analysis of these variables, taking into account the industry in which the borrower was carrying out the campaign. Some of the main insights are:

a) The agriculture category is the industry with the most loans (20\% of all loans) and also has the lowest average loan amount (\$155) and the shortest overall payment period (114 days). However, this category has the highest number for days to fund both for the average (23) and median (18). It is paradoxical that the loan category with the lowest amount and the shortest payment period is the one that takes the longest time to fund.

b) The healthcare category shows opposing characteristics to those of agriculture since it has the lowest number of days to fund its campaigns (an average of 11 and a median of 7) but it has the highest average amount (\$288) and the longest average payment period (160 days).

c) The categories of arts/crafts, energy, transportation, and retail - wholesale also have a paradoxical relationship between the size of the loan and the days it takes to fund it. These industries have most of the largest average loan amounts but some of the lowest average numbers of days to fund the loans. 


\section{Table 15}

Days to fund projects by campaign industry

\begin{tabular}{lccccccc}
\hline Campaign industry & $\begin{array}{c}\text { Camp } \\
\text { aigns }\end{array}$ & $\begin{array}{c}\text { Loan } \\
\text { mean }\end{array}$ & $\begin{array}{c}\text { Loan } \\
\text { median }\end{array}$ & $\begin{array}{c}\text { Funding } \\
\text { days } \\
\text { mean }\end{array}$ & $\begin{array}{c}\text { Funding } \\
\text { days } \\
\text { median }\end{array}$ & $\begin{array}{c}\text { Payment } \\
\text { period } \\
\text { mean }\end{array}$ & $\begin{array}{c}\text { Payment } \\
\text { period } \\
\text { median }\end{array}$ \\
\hline Agriculture & 1,925 & 155 & 125 & 23 & 18 & 114 & 91 \\
Food stall/grocery & 1,667 & 187 & 125 & 17 & 8 & 127 & 91 \\
Clothing/jewelry/accessories & 1,562 & 196 & 125 & 19 & 12 & 131 & 91 \\
Retail - general & 1,226 & 200 & 125 & 21 & 13 & 131 & 91 \\
Services & 867 & 201 & 125 & 18 & 9 & 131 & 91 \\
Other & 796 & 194 & 125 & 20 & 9 & 126 & 91 \\
Beauty/cosmetics & 532 & 186 & 125 & 21 & 14 & 122 & 91 \\
Arts/crafts & 246 & 220 & 150 & 12 & 7 & 145 & 91 \\
Energy & 229 & 259 & 225 & 14 & 8 & 148 & 91 \\
Healthcare & 167 & 288 & 250 & 11 & 7 & 160 & 152 \\
Transportation & 164 & 221 & 225 & 17 & 8 & 134 & 91 \\
Retail - wholesale & 126 & 203 & 200 & 16 & 8 & 130 & 91 \\
Housing/ construction & 114 & 221 & 125 & 20 & 13 & 134 & 91 \\
Total & 9,621 & 191 & 125 & 19 & 12 & 127 & 91 \\
\hline
\end{tabular}

Source: Prepared by the authors based on https://zip.Kiva.org/, last accessed February 2017.

\subsection{Repayment of Loans}

The success of a crowdlending campaign can be defined as a project raising the requested funds in the allotted time (as defined by the platform) and also paying back the loan according to the established conditions (loan terms). Kiva Zip has managed to raise funds for all but 19 campaigns. However, it has room for improvement in the repayment of loans.

Kiva Zip in Kenya has successfully funded and collected payment for 76\% of the listed campaigns, which account for 70\% of the requested resources. (The difference between these two percentages is explained by the fact that loans are for different amounts.) For those loans with the status "paying back," it is estimated that 72\% are late, which we define as when a loan has not been paid back in full by the date established in the loan terms.

It must be understood that Kiva Zip does not disclose publicly the specific payment status of the loans with the status "paying back." The organization decided to do this since it wanted to prevent those borrowers who are behind on their payments from being harassed or publicly shamed. Only the project's lenders may see this information. ${ }^{24}$ At the moment, $18 \%$ of loans are considered to be late in being paid back. Nevertheless, it is not clear whether the amount owed is equal to the full amount of the loan or only a proportion of it, in the case of some payments having been made.

However, not all late payments are the same, since the probability of a loan being collected may be different if it is one month or two years late. Of the 2,292 campaigns that are still being paid pack, 28\% are on schedule, 29\% are delinquent (considered by Kiva Zip as those loans that are late in being paid back by less than six months) and $43 \%$ are defaulted (considered by Kiva Zip as those loans that are late in being paid back by six months or more).

\footnotetext{
${ }^{24}$ https://zip.Kiva.org/faq, last accessed November 2016.
} 


\section{Table 16}

Status of loans

\begin{tabular}{|c|c|c|c|c|c|c|c|c|c|c|}
\hline & & & \multicolumn{6}{|c|}{ Paying back } & \multirow[b]{2}{*}{ Total } & \multirow[b]{2}{*}{$\%$} \\
\hline & Paid back & $\%$ & On schedule & $\%$ & Delinquent & $\%$ & Defaulted & $\%$ & & \\
\hline Campaign funds & $1,287,788$ & 70 & 216,270 & 12 & 148,284 & 8 & 185,009 & 10 & $1,837,351$ & 100 \\
\hline Campaign count & 7,329 & 76 & 636 & 7 & 674 & 7 & 982 & 10 & 9,621 & 100 \\
\hline
\end{tabular}

Source: Prepared by the authors based on https://zip.Kiva.org/, last accessed February 2017.

\section{Table 17}

Lateness of uncollected loans

\begin{tabular}{|c|c|c|c|c|c|c|c|c|c|c|c|c|}
\hline & & & \multicolumn{8}{|c|}{ Late payments } & \multirow[b]{2}{*}{ Total } & \multirow[b]{2}{*}{$\%$} \\
\hline & On schedule & $\%$ & $\begin{array}{c}0 \text { to } 3 \\
\text { months }\end{array}$ & $\%$ & $\begin{array}{c}3 \text { to } 6 \\
\text { months }\end{array}$ & $\%$ & $\begin{array}{l}6 \text { to } 12 \\
\text { months }\end{array}$ & $\%$ & $\begin{array}{c}>12 \\
\text { months }\end{array}$ & $\%$ & & \\
\hline Campaign funds & 216,270 & 39 & 91,764 & 17 & 56,520 & 10 & 104,014 & 19 & 80,995 & 15 & 549,563 & 100 \\
\hline Campaign count & 636 & 28 & 413 & 18 & 261 & 11 & 568 & 25 & 414 & 18 & 2,292 & 100 \\
\hline
\end{tabular}

Source: Prepared by the authors based on https://zip.Kiva.org/, last accessed February 2017. 
On Kiva Zip Kenya, 76\% of the projects and 70\% of the funds have been paid back in full and 6,621 borrowers have received a friendly loan that has helped them improve their own financial situation and that of their community. In this light, the late payment rates of $17 \%$ of projects and $18 \%$ of granted amounts may not be as harmful as they seem. A lender, who accepts a 100\% risk with a $0 \%$ premium in return for lending in Kenya, may be satisfied just by helping others and may not be so demanding in terms of a financial return. This does not mean that Kiva Zip should not perform due diligence on borrowers and trustees but that the crowdlending organization should understand that it should not demand the same rigor and performance as in operations based on Kiva.org, where a project has a field partner who has a closer relationship to the borrower and consequently makes it easier to ensure that loan payments are collected.

Another angle for analyzing the defaulted campaigns is to look at the characteristics of the loans (loan terms). First, we have seen that loans can be paid back in weekly, fortnightly or monthly installments. For Kiva Zip, it is interesting to observe how campaigns that have monthly payments have a late payment rate of $15 \%$, which is better than the $18 \%$ for campaigns with weekly payments and 30\% for those with fortnightly payments. This can be understood as meaning that the more spaced out the payments are, the less likely a campaign is to be late with payments. Lateness with payments may be caused by a misalignment between the cash flows of the business and the repayment terms. Unfortunately, borrowers may be overoptimistic regarding their capacity to generate a profit from their venture and so commit themselves to frequent payments that are complicated to fulfill once they start operating their venture.

\section{Table 18}

Payment frequency and late-paying campaigns

\begin{tabular}{lccccc}
\hline $\begin{array}{l}\text { Payment } \\
\text { frequency }\end{array}$ & $\begin{array}{c}\text { Funded } \\
\text { campaigns }\end{array}$ & $\begin{array}{c}\text { Amount } \\
\text { funded (\$) }\end{array}$ & $\begin{array}{c}\text { Late-paying } \\
\text { campaigns }\end{array}$ & $\begin{array}{c}\text { Lateness } \\
\text { rate }\end{array}$ & $\begin{array}{c}\text { Average loan } \\
\text { amount }\end{array}$ \\
\hline Weekly & 6,256 & $1,202,989$ & 1,136 & $18 \%$ & 192 \\
Fortnightly & 120 & 41,025 & 36 & $30 \%$ & 342 \\
Monthly & 3,245 & 593,337 & 484 & $15 \%$ & 183 \\
Total & 9,621 & $1,837,351$ & 1,656 & $17 \%$ & 191 \\
\hline
\end{tabular}

Source: Prepared by the authors based on https://zip.Kiva.org/, last accessed February 2017.

In addition to payment frequency, the length of the overall loan payment period also has an important relationship with the likelihood that a campaign will default. Campaigns that promise to pay in less than 180 days have a lateness rate of $17 \%$, while those campaigns that establish a payback period of between 180 and 360 days have a default rate of 20\%. It is important to note that $84 \%$ of campaigns have an overall payment period of 180 days or less. Further research may provide insight regarding the optimal loan payment period for small entrepreneurial ventures. 


\section{Table 19}

Loan payment period (days to pay back the loan) and late-paying campaigns

\begin{tabular}{lccc}
\hline Length of loan (days) $^{25}$ & Funded campaigns & Late-paying campaigns & Lateness rate \\
\hline$<30$ & 16 & 1 & $6 \%$ \\
30 to 60 & 344 & 47 & $14 \%$ \\
60 to 90 & 3,238 & 515 & $16 \%$ \\
90 to 120 & 2,610 & 361 & $14 \%$ \\
120 to 150 & 438 & 132 & $30 \%$ \\
150 to 180 & 1,474 & 301 & $20 \%$ \\
180 to 210 & 246 & 36 & $15 \%$ \\
210 to 240 & 269 & 57 & $21 \%$ \\
240 to 270 & 474 & 104 & $22 \%$ \\
270 to 300 & 245 & 57 & $23 \%$ \\
300 to 330 & 11 & 3 & $27 \%$ \\
330 to 360 & 29 & 1 & $3 \%$ \\
$>360$ & 227 & 41 & $18 \%$ \\
Total & 9,621 & 1,656 & $17 \%$ \\
\hline
\end{tabular}

Source: Prepared by the authors based on https://zip.Kiva.org/, last accessed February 2017.

The length of the loan, which is the number of days that the borrower has in which to pay back the loan, has two elements: term days and grace days. Term days refer to the maximum number of days that the borrower has in which to pay back the loan, and grace days are the number of days that the borrower has between receiving the funds and starting the term days period.

Grace days may be beneficial to borrowers since this period gives them some time to prepare the business before revenues start coming in, when they need some days to start the business and build up some working capital in order to become stable enough to begin paying back the loan. Of those campaigns that requested grace days (either one or two months), 58\% of them were late with payments. On the other hand, the default rate for funded campaigns that did not ask for grace days was 17\%.

\section{Table 20}

Grace days and late-paying campaigns

\begin{tabular}{lcrcc}
\hline Grace days & Funded campaigns & $\%$ & Late-paying loans & Lateness rate \\
\hline N/A & 9,485 & 99 & 1,577 & $17 \%$ \\
1 month & 47 & 0 & 18 & $38 \%$ \\
2 months & 89 & 1 & 61 & $69 \%$ \\
Total & 9,621 & 100 & 1,656 & $17 \%$ \\
\hline
\end{tabular}

Source: Prepared by the authors based on https://zip.Kiva.org/, last accessed February 2017.

Finally, the amount of the loan may affect how likely it is that a loan will not be paid back on time. Of all loans, $62 \%$ were granted for $\$ 125$ or less and had a lateness rate of $15 \%$, while loans above $\$ 125$ (the remaining 38\% of all loans) had a lateness rate of $20 \%$.

\footnotetext{
${ }^{25}$ Includes loan term days and grace days.
} 


\section{Table 21}

Loan amount and late-paying campaigns ${ }^{26}$

\begin{tabular}{|c|c|c|c|c|c|c|c|}
\hline Loan amount (\$) & Campaigns & $\begin{array}{l}\text { Delinquent } \\
\text { campaigns }\end{array}$ & Delinquency rate & $\begin{array}{l}\text { Defaulted } \\
\text { campaigns }\end{array}$ & Defaulted rate & $\begin{array}{l}\text { Late-paying } \\
\text { campaigns }\end{array}$ & Lateness rate \\
\hline$<125$ & 5,971 & 301 & $5 \%$ & 623 & $10 \%$ & 924 & $15 \%$ \\
\hline 125 to 250 & 2,142 & 203 & $9 \%$ & 223 & $10 \%$ & 426 & $20 \%$ \\
\hline 250 to 375 & 1,261 & 158 & $13 \%$ & 118 & $9 \%$ & 276 & $22 \%$ \\
\hline 375 to 500 & 51 & 4 & $8 \%$ & 3 & $6 \%$ & 7 & $14 \%$ \\
\hline 500 to 625 & 151 & 5 & $3 \%$ & 6 & $4 \%$ & 11 & $7 \%$ \\
\hline 625 to 750 & 15 & 1 & $7 \%$ & 2 & $13 \%$ & 3 & $20 \%$ \\
\hline 750 to 875 & 33 & 2 & $6 \%$ & 3 & $9 \%$ & 5 & $15 \%$ \\
\hline$>875$ & 16 & 0 & $0 \%$ & 4 & $25 \%$ & 4 & $25 \%$ \\
\hline
\end{tabular}

Source: Prepared by the authors based on https://zip.Kiva.org/, last accessed February 2017.

${ }^{26}$ A campaign is considered late if the loan has not been paid back in full by the established date. A late-paying campaign can be either delinquent or defaulted. It is delinquent when the loan is less than six months late and it is defaulted when it is six months or more late.

32 - IESE Business School-University of Navarra 


\section{Further Research}

Subsequent to this article, the authors wish to undertake a more in-depth analysis in order to understand better the theoretical perspective of the crowdfunding, peer-to-peer lending and prosocial crowdlending industries through a quantitative and qualitative research approach. We will use Kiva Zip's operations in Kenya as a starting point for this analysis. Specifically, we wish to address the following research questions:

1. How do the formal and informal controls in crowdfunding platforms align with the firm's goals? This question is relevant since, through explicit and implicit sets of rules, platforms seek to enhance their operations. However, there is a risk that the way in which managerial control systems are designed and used (CugueróEscofet, 2016) will fail to promote goal congruence.

2. How do cultural dimensions, such as uncertainty avoidance or collectivism, moderate the relationship between the dependent variables (e.g., project characteristics, loan details and competition) and the likelihood of a campaign being funded? This analysis may facilitate an understanding of whether the industry is more universal or idiosyncratic across cultures.

3. What are the variables that increase the likelihood of a campaign being funded? Once this is understood, it will be possible to make inferences about lenders' interests.

4. What is the funding pattern of a peer-to-peer prosocial crowdlending campaign? This may provide insight into herding behavior and into the early prediction of funding.

5. What are the variables that predict loan delinquency or defaults? A logistic regression model could help identify variables that might predict at an early stage any lateness in payments. Consequently, this could allow adverse selection to be decreased in crowdfunding campaigns.

6. Are lenders of crowdfunding campaigns better than experts? The idea that the industry is meritocratic and that the crowd can be a good evaluator of a campaign's feasibility can be put to the test. Lenders may have certain criteria when determining the campaigns that they want to fund. Is probability of success one of those criteria? Or do lenders just want to support a cause they believe in?

These six questions have the potential to be explored rigorously, to prepare the foundations for interesting quantitative and qualitative approaches. 


\section{Concluding Remarks}

Kiva Zip has made a remarkable endeavor to promote social entrepreneurial projects through a crowdlending platform that allows borrowers to access capital with a $0 \%$ interest rate. The organization started this project in Kenya, a country where unfortunately more than $40 \%$ of its citizens are poor and whose GDP per capita represents less than 5\% of that of the United States, where Kiva Zip currently operates. Loans in Kenya can help people such as Angelica Murangi Njiru, a nurse in an impoverished town who wanted $\$ 125$ to invest in more medicine for her store, or Atabo, a farmer in Lodwar who needed a loan for the same amount in order to purchase a generator for his water pump, which would allow him to irrigate his field more efficiently. These stories may give readers an idea of the nature of the loans on the Kiva Zip Kenya platform.

Kiva Zip's lenders have funded 9,621 loans - 99.8\% of the 9,640 listed loans - and have collected full payment for $76 \%$ of them. Of the $24 \%$ of campaigns that had not yet been paid back, $28 \%$ were on schedule, 29\% were delinquent (less than six months late) and 43\% were defaulted (six months or more late).

After operating from November 2011 to September 2015, Kiva Zip decided to stop posting new campaigns in Kenya and continued only with the collection of previously disbursed loans in that country although it remained fully operational in the United States. We feel that this decision may not be aligned with the firm's mission, which is "to connect people through lending to alleviate poverty." Our analysis may provide some insight into areas for improvement that could have enabled Kiva Zip to achieve better results in Kenya.

Kiva Zip is a platform and organization that could do great good in low-income countries. Instead of trying to impose limits or taking the firm to less risky regions, it could focus on how to improve operations in countries where it is needed the most. 


\section{References}

Adler, N. J. (1983), A Typology of Management Studies Involving Culture. Journal of International Business Studies, 14(2), pp. 29-47.

Akerlof, G. A. (1970), The Market for "Lemons": Quality Uncertainty and the Market Mechanism. The Quarterly Journal of Economics, 84(3), pp. 488-500.

Alegre, I., and M. Moleskis (2016), Crowdfunding: A Review and Research Agenda. IESE Business School working paper, WP-1142-E.

Allison, T. H., A. F. McKenny, and J. C. Short (2013), The Effect of Entrepreneurial Rhetoric on Microlending Investment: An Examination of the Warm-Glow Effect. Journal of Business Venturing, 28(6), pp. 690-707.

Andreoni, J. (1990), Impure Altruism and Donations to Public Goods: A Theory of Warm-Glow Giving. The Economic Journal, 100(401), pp. 464-477.

Battilana, J., and S. Dorado (2010), Building Sustainable Hybrid Organizations: The Case of Commercial Microfinance Organizations. Academy of Management Journal, 53(6), pp. 1,419-1,440.

Burtch, G., A. Ghose, and S. Wattal (2013), An Empirical Examination of the Antecedents and Consequences of Contribution Patterns in Crowd-Funded Markets. Information Systems Research, 24(3), pp. 499-519.

Burtch, G., A. Ghose, and S. Wattal (2014), Cultural Differences and Geography as Determinants of Online Prosocial Lending. MIS Quarterly, 38(3), pp. 773-794.

Cugueró-Escofet, N., and J. M. Rosanas (2016), The Ethics of Metrics: Overcoming the Dysfunctional Effects of Performance Measurements Through Justice. Journal of Business Ethics, 133(2), pp. 1-17.

Galak, J., D. Small, and A. T. Stephen (2011), Microfinance Decision Making: A Field Study of Prosocial Lending. Journal of Marketing Research, 48, S130-S137.

Hofstede, G. (1983), The Cultural Relativity of Organizational Practices and Theories. Journal of International Business Studies, 14(2), pp. 75-89.

Ibarra Garza, A., N. Cugueró-Escofet, and M. A. Canela (2016), Default Prediction in Prosocial Crowdlending. Working paper.

Ibarra Garza, R., and A. Ibarra Garza (2016), Crowdfunding: The Mexican Context. Working paper.

Jeng, L. A., and P. C. Wells (2000), The Determinants of Venture Capital Funding: Evidence Across Countries. Journal of Corporate Finance, 6(3), pp. 241-289.

Kshetri, N. (2015), Success of Crowd-Based Online Technology in Fundraising: An Institutional Perspective. Journal of International Management, 21(2), pp. 100-116.

Merchant, K. A. (1982), The Control Function of Management. Sloan Management Review, 23(4), pp. 43-55.

Messier, W. F., and J. V. Hansen (1988), Inducing Rules for Expert System Development: An Example Using Default and Bankruptcy Data. Management Science, 34(12), pp. 1,403-1,415. 
Moleskis, M., I. Alegre, and M. A. Canela (2016), Attraction of Funding in Hybrid Organizations: Charity or Venture Capitalism? Working paper.

Moleskis, M., and M. A. Canela (2016), Crowdfunding Success: The Case of Kiva.org. IESE Business School working paper, WP-1137-E.

Mollick, E., and R. Nanda (2015), Wisdom or Madness? Comparing Crowds With Expert Valuation in Funding the Arts. Management Science, 62(6), pp. 1,533-1,553.

N'Guessan, M. N., I. Alegre, and M. A. Canela (2016), Crowdfunding in Africa: How Crowdfunding Platforms Have Shaped African Entrepreneurial Landscapes. Working paper.

Nolan, D., and D. Temple Lang (2014), XML and Web Technologies for Data Sciences With R. Springer-Verlag, New York.

Pauly, M. V. (1974), Overinsurance and Public Provision of Insurance: The Roles of Moral Hazard and Adverse Selection. The Quarterly Journal of Economics, 88(1), pp. 44-62.

Peres, R., E. Muller, and V. Mahajan (2010), Innovation Diffusion and New Product Growth Models: A Critical Review and Research Directions. International Journal of Research in Marketing, 27(2), pp. 91-106.

Rosanas, J. (2008), Beyond Economic Criteria: A Humanistic Approach to Organizational Survival. Journal of Business Ethics, 78(3), pp. 447-462.

Shapiro, C., and H. R. Varian (1999), Information Rules. Harvard Business School Press, Boston, Massachusetts.

Surowiecki, J. (2005), The Wisdom of Crowds. Anchor Books, New York.

Ouchi, W. (1979), A Conceptual Framework for the Design of Organizational Control Mechanisms. Management Science, 25(9), pp. 833-848.

Zhang, J., and P. Liu (2012), Rational Herding in Microloan Markets. Management Science, 58(5), pp. 892-912. 